\title{
The Problem of the Lesser Sandhill Crane
}

by Lawrence H. Walkinshaw, Battle Creek, Michigan.

Photos by the author.

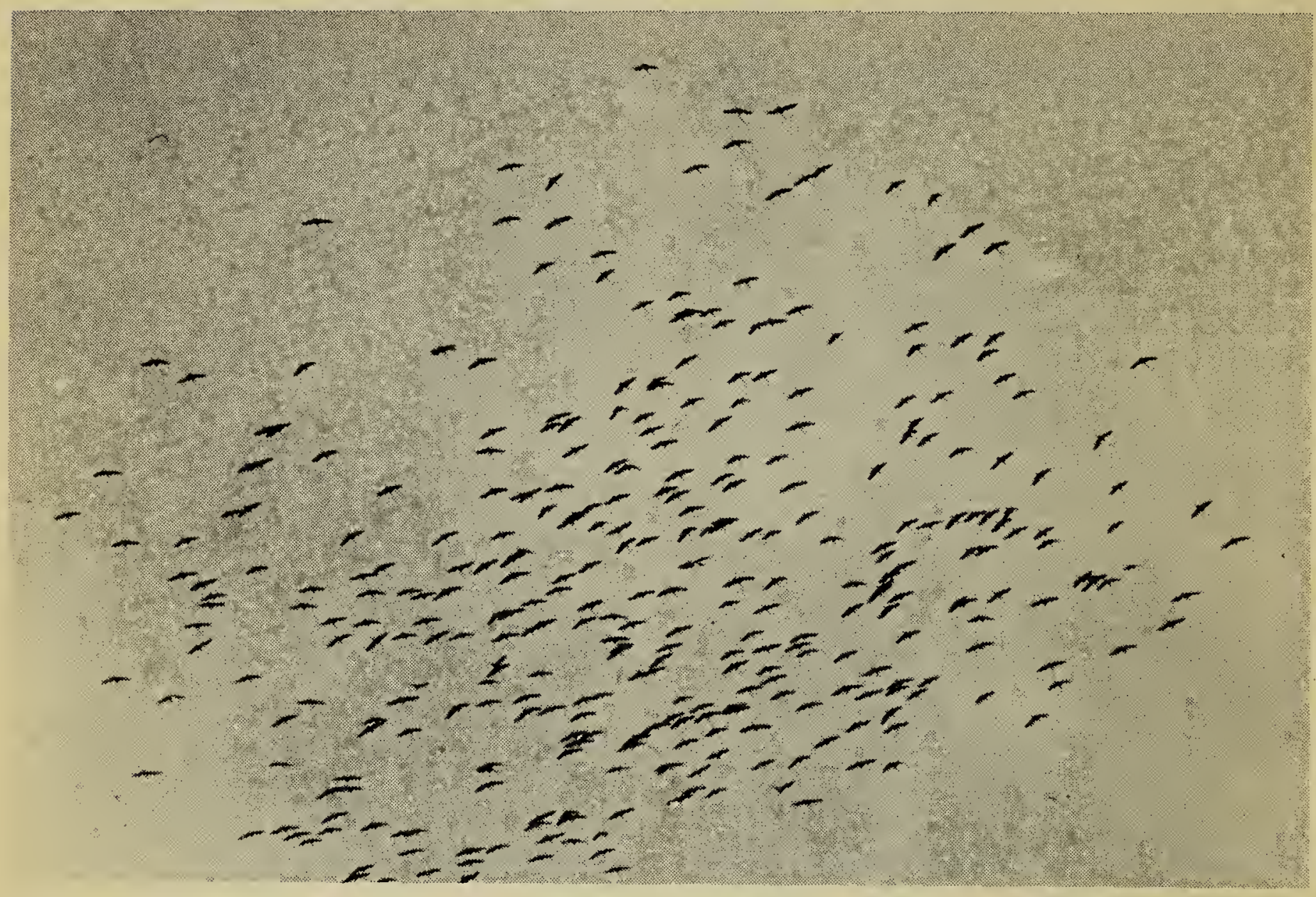

Flight of Sandihills, Manch 26, 1954, Hershey, Nebraske.

Out of the Arctic each fall come the Lesser Sandhill Cranes (Grus canadensis canadensis), the majority migrating along their traditional route, reaching a concentration point in south-central Saskatchewan. Later they move slightly east and southward to their winitering grounds:

Dementiev and Gladkov (1051:115) wrote that Sandhill Cranes in the Anadyr region, nontheastern Siberia, began to group into flocks, young with their parents, by the 20th of August and they begin to fly south, prolonging this until mid-September and even to the end of the month. At Anadyr Bay the departure wlas August 29 to September 13, 1930; at the mouth of the Tanyurera River, last virds were seen on September 15. 1931 (there was $18 \mathrm{~cm}$. of snow here on September 14); and in 1932 at Novomariinck the last birds were observed September 9.

This period agnees with western Alaskan migration dates which I listed in The Sandhill Cranes (1949: 168). Brina Kessel (letter to author) wrate that she saw about 150 cranes in flocks of 10 to 50 migrating August 25, 1952 at 7 p.m. at Fairbanks, Alaska, and heard many cranes Augusit 17, 1955. She ailso observed a flock of 90 passing aver the college. September 4, 1955. Smith (1958:51; 1959:56 and 1960:64) wrote that an estimated 400-500 cranes went through the Cahoe, Allaska, district, September 8 to 14,1957 , while the majority moved out Sepitember 18, 1958 , prior to a front, followed by the last on Octaber 8, and a flock went over September 26, 1959. Manning et al. (1956:56), wrote that cranes left the nonth shore of Banks Isliand, northern Canadia, August 24, 1952; a t Back Point, August 18, 1953, and from the east coast Septemiber 1, 1953.

Rand (1944:117) saw a great filight through the Font Nelson area, British Columbia with flocks totalling 500 passing overheid, Sepitemiber 16, 1943 and he observed athers on September 15 and 17. William Rowran (letter to author) wrate: "Cranes migrate through here in counitless thousands. I find them much scarcer in the spring than in the fall. The main mignation 
often starts before the middle of September, but the latter half is more typical. Harrold and I ance estimated that we hard some 30,000 cranes over our tenit in one day, 50 miles east of Edimonton. During the early huniting season one ofiten sees cranes gaing south-east all day while every other hunter everywhere else seemis to have the same experience in Albenta."

Some Sandhill Cranes arrive in the Saskatchewan farming areas by August 1 (Munro, 1950). Gradually accumulating into lange flocks in certain areas by mid- to late August, some remain into mid-October. Probably the individual content of the flock varies from time to time as the birds move on southwlard and others come from the north and northwest. 'The Last Mountain Lake Sanctuary created in 1887 and described in the Blue Jay (1960:71) is the area used by the largest number of birds in Saskatchewan but it is completely surrounded by farm land. The farm land is used primarily to raise wheat and Sandhill Cranes like wheat and other grains. They roost in shallow water trien fly early in the morning to available food which in this case is grain.

In 1935 and 1936 and thereabouts, many wildlife refuges were set up in the United Staites. Many of these were in the Dakotas, Montana, New Mexico and Texas. Primarily for the protection of waterfowl, these have also served well for other species, including the Sandhill Crane.

The Lesser Sandhill Crane nests in the Arctic, from northeastern Siberia, through Alaska and across northern Canada, north to Banks Island and eastward to Baffin Island and Southampton Island, southward at least to Great Slave Lake and Churchill, Manitaba, and possibly farther southward. This distribution has changed little during our times. Probably the numbers of hunting Eskimos have produced no severe damage to cranes at any time (I suggest that we consider the Sandhill Crane as a food source for Eskimos). Consequently the loss of cranes reported by Bailey (1928) must have been in southern Canada and in the United States. This definitely must have been caused by hunting pressure, probably chiefly in the United States in winter. This was the same period when the Whooping Crane (Grus americana) disappeared and those Greater Sandhill Cranes (G.c. tabida) from the southern Great Plains, Canadian Provinces and states such as the Dakotas, eastern Mcntana and Nebraska. The cranes of southern Manitoba, Minnesota and Iowa disappeared at the same time, as well as the great flocks of cranes that used to migrate over Iowa and Missouri and those wintering in Louisiana.

The wintering range of the Lesser Sandhill Crane extends frcm southern California, probably as far nonth as Portland, Oregon, eastward to the Texas panhandle and to scutheastern Texas and southwand into Mexico with reports from San Luis Poitosi and even farther southward.

In Christmas counts made throughout North America in the pasi 40 years, there were practically no Sandhill Crane reports until 1938 when 91 were listed from Aransas National Wildlife Refuge, Texas: During 1957, 425 were counted here, in 1958,75 and in 1959, 36. At San Benito at the Laguna Atascosa $\mathrm{Na}-$ tional Wildlife Refuge 68 cranes were counted in 1953-54; 742 in 1954-55; 632 in $1955 ; 491$ in $1956 ; 776$ in 1957; 1,761 in 1958 and anly 32 in 1959. At Carrizo Springs, Texas, 1,900 cranes were counted in 1957 and 700 in 1.58 and at Stanton, Texas, 18,967 in 1959. At Muleshoe National Wildlife Refuge, Bailey County, Texas; the counts have been $1942 \quad(850) ; 1944$ $(5,052) ; 1945 \quad(1,120) ; 1949$ (188); $1953(12,000) ; 1954(15,000) ; 1955$ $(30,000) ; 1956 \quad(41,000) ; 1957$ $(55,000) ; \quad 1958 \quad(36,000) ; \quad 1959$ $(18,500)$. Other Texas areas where cranes were listed were Alamo, Alice, Big Springs, Cove, Del Rio, Eagle Pass, El Paso, Freeport, Harlingen, Houston, La Sal Vieja, Midland, Odessa, Palmetto State Park, Pyate, Richmond, Rockport, Sabinal, Tivoli, and Welder Wildlife Refuge. At the same time cranes apparently winter over much of western Texas where shallow water in lakes or streams offers roasting areas and when winters are not too cold.

Cranes were reponted from New Mexico at Bitter Lakes National Wildlife Refuge, Roswell, 1942 $(5,772) ; 1943 \quad(6,012) ; 1949 \quad(800)$; $1950(11,005) ; 1951 \quad(11,635) ; 1952$ $(13,477) ; 1954(6,763) ; 1954(6,049)$; $1955(14,000) ; 1956(35,000) ; 1957$ $(20,000) ; 1958 \quad(22,750) ; \quad 1959$ $(12,350)$. At Basque del Arache Na- 


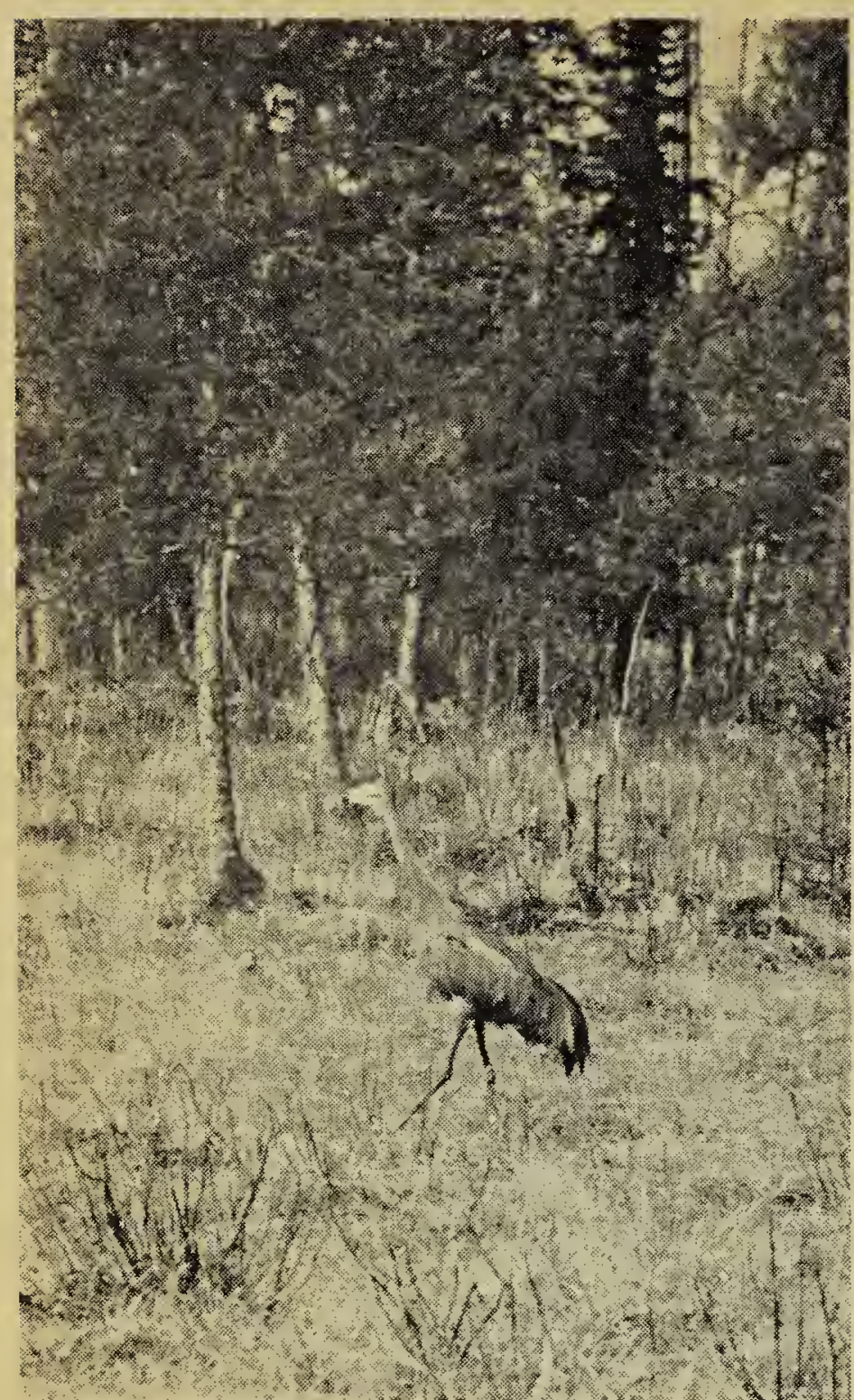

Sandhill Crane at nest site, May 30, 1942, Fawcett, Alberta.

tional Wildlife Refuge, San Antonio, New Mexico, 1948 (200); 1949 (66); 1950 (116); 1952 (310); 1953 (6); $1954 \quad(1,237) ; 1955 \quad(850) ; 1956$ $(1,084) ; 1957(1,219)$. They were also reported from Carlsbad Caverns $\mathrm{Na}-$ tional Park, Virden and Socorro; at Kearney, Nebnaska, January 1, 1959 (1) ; Reno, Nevada, in 1958 (3); Portland, Oregon, December 26, 1948 (42), December 29, 1957 (20) and at Tillamook, Oregon, December 26, 1949 (6).

In Californila, at Chico, 1957 (26); Gray Lodge Wildlife Refuge, 1952 (28), 1954 (426); Lodi, 1953 (510), 1955 (4,021), 1958 (16); Marysville, 1957 (12); Orange County, 1951 (1); Red Bluff, 1952 (38), 1953 (350), 1955 (650); Redding, 1958 (6) (28); Salton Sea, 1939 (279), 1956 (3). The crane has almost disappeared here in winter. Cranes were observed at Sacramento: 1944 (39), 1950 (10), 1955 (2), 1958 (130); and at Stockton, 1951 (250), 1952 (500). Probably the largest winter concentration in Cali- fornia now is at the Carissa Plain, at Soda Lake; San Luis Obispo County, where Eben MaMillan (letters: to author) has estimated about 5,000 cranes in some yeiars and down to 500 in other years depending on drought conditions. In January, 1947, a flight of 3,200 cranes headed out from the plain in groups of one to 300. In 1960-61 this concentration was about 10,000. Another recent California concentration area was south of King City, Monterey County, where 1,000 cranes were observed February 12, 1959 (Cuitler and Pugh, 1959). From existing specimens, both canadensis and tabida winter in that state but the majority are canadensis. There are a number of specimens which were taken in 1897, 1898, 1909 and 1912 at Los Banos in winter and this area was used even up until March 13-14, 1929 (McLean, 1930). In earlier days cranes used to occur in the San Francisco region in winter.

The complete Christmas count Sandhill Crane total has been as follows (this included C.c. pratensis in Georgia and Florida): 1923-1931, none; 1932,$2 ; 1934,4 ; 1938$ (2) (201); 1939 (3) $363 ; 1942$ (4) 6,$742 ; 1943$, 6,012 ; 1944 (2) 5,091 ; 1945 (2) 1,163 ; 1946 (2) $19 ; 1947$ (4) $249 ; 1948$ (3) 253 ; 1949 (8) 1,237 ; 1950 . (7) 11,659 ; 1951 (8) 12,254 ; 1952 (14) 14,653; 1953 (13) 20,156 ; 1954 (17) 29,255 ; 1955 (16) 46,503 ; 1956 (18) 80,135 ; $1957 \quad$ (25) 80,577 ; 1958 (24) 62,142; and 1959 (25) 50,602 .

All of the North American cranes have increased in numbers since 1940 but probably G.c. canadensis has increased the most because there were more to begin with. The majority of these winter in central California, eastern New Mexico and western Texas and no one knows how many nor entirely where in Mexico. Older specimens exist from Cerro Prieto, Baja, California; Rio Verde, San Luis Potosi; La Barca, Jalisco; and a specimen of tabida from Borbon, Mexico. Sight records of cranes have been made in winter: Oregon: mouth of the Columbia River by Lewis and Clark (probably authentic in view of recent Portland and Tillamook observations). One wintered at Mialheur National Wildlife Refuge, Harney County, in the early 1940's (letter, U.S. Fish and Wildlife Service). There are winter records of lone individuals from Milwaukee, Wiscon- 
sin and Jackson County, Michigan. Frank W. Robl (leitters) had cranes winter at his place at Ellinwood, Kansas, from 1927 for several years; one was shot in Lawrence Counity at Marionville, Missouri, in January, 1920 (Harris, 1920). The Nices (Birds of Oklahoma) list winter birds from Beaver, Washita and Tillman counties, Oklahoma. Cooke (1897) wrote that cranes wintered in Colorado in the Rio Grande Valley by the thousands. In California winter records are from Tehama, Stanislaus, Merced, San Joaquin, Fresno, Kings, San Luis Obispo, Los Angeles, Orange, Riverside and Imperial counties; in Arizona along the Colorado River Valley, and the Aqua Fria and San Pedro rivers, more recently at Ehrenburg, Gila Bend, Peoria (Maricopa County), Arlingiton State Waterfowl area, Theba, and Parker (Gale Monson Aud. Field Notes); in New Mexico in Bernalillo, Sante Fe, Socorro, Roosevelt, Chaves and Eddy counties; the species has been found then over most of the Texas panhandle south to El Paso and east to Houston, Aransas National Wildlife Refuge and the Brownsville area.
These counts indicate an increase rather than a decrease in the number of cranes, which at first seems incompatible with the decrease in suitable habitat. Cranes, however, were decreasing in number unitil the creation of the wildlife sanctuaries in the 1930's. The increase has come since then, indicating that fewer birds have been killed or have died in migration or in the winter in these protected areas, due to less disease or better food or both, and to less shooting by natives.

The great problem with the Sandhill Cranes is the problem of crop damage. The areas of greatest crop damage are the areas of greatest concentrations: Carissa Plain, California; Bittier Lakes National Wilddifie Refuge, New Mexico; Muleshoe National Wild liffe Refuge, Texas; Lower Souris National Wildlife Refuge, North Dakota; Last Mountain Lake, Saskatchewan. The nature of the damage differs from area to area because of different crops and harvesting conditions. In Mexico, Texas and New Mexico much corn and related sorghums are raised; in Indiana and in Michigan, corn and wheat; in

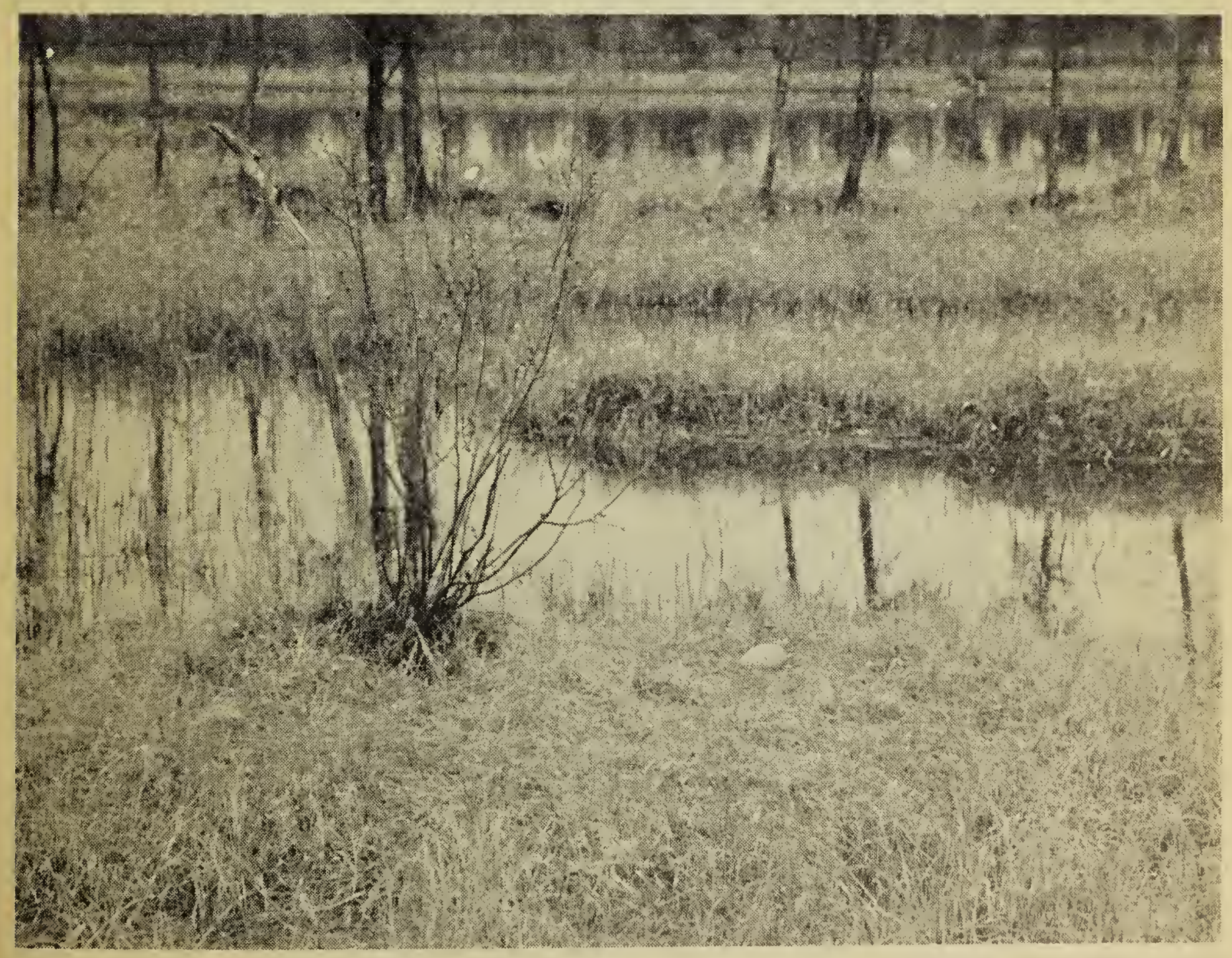

Nest of Sandhill Crane at Fawcett, Alberta, May 21, 1942. 


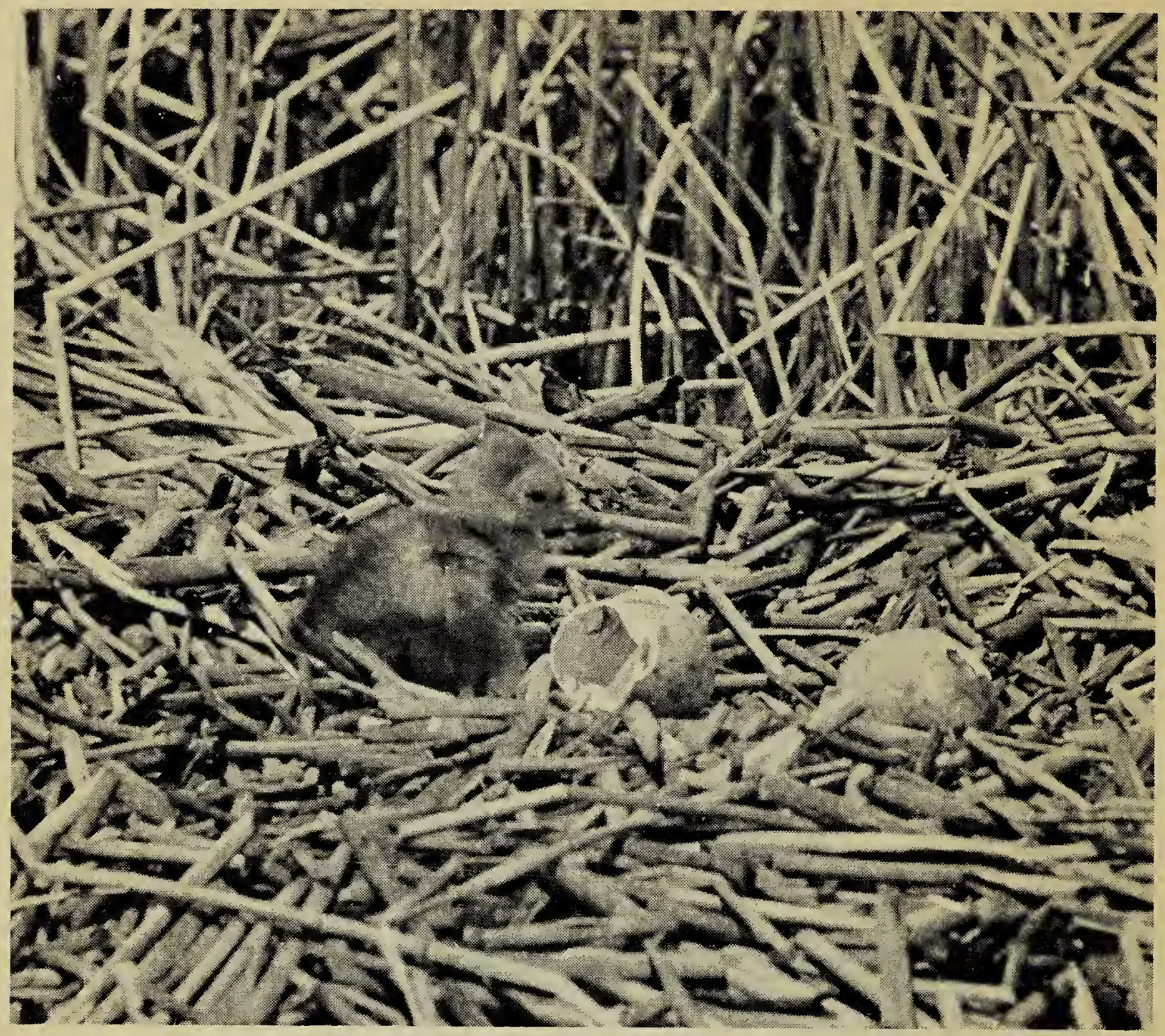

Sandhill Crana neot, Caribou County, Idaho, May 24, 1941.

North Dakota, Saskatchewan, and the Carissa Plain, California, wheat. In Texas and New Mexico the grain is planted in spring, but it is already cut and in shocks when the cranes arrive and could probably be stacked if further protection were needed. In California wheat is apparently planted in the fall as in Indiana and Michigan, and there cranes eat the wheat nat buried by the drill. Eben McMillan writes that they also browse over the new green wheat in California but no ane has produced evidence that this browsing has produced any damage. In Saskatchewan and North Dakota, wheat has to be planted in the spring but in many areas it is not harvested until early September, whereas the cranes begin to return in August. Munro (1950) found that cranes in Saskatchewan were eating $53.7 \%$ wheat. About $90 \%$ of the stomach contents of five birds I found near Hershey, Nebraska, on March 22, 1954, consisted of corn and oat hulls, and of course loose corn in the fields provides winter and spring forage for cattle.

Because cranes are not decreasing in numbers and because suitable marsh habitat is constantly being drained, crop damage is not going to decrease in the future. Who should assume responsibility for this crop damage? Because a farmer lives adjacent to a roosting area should he be required to feed thousands of cranes? Surely this would be unjust! The oranes belong to all the people of Canada, the United States and Mexico, and the governments of these three countries are therefore jointly responsible. If we want cranes, all of us should help to meet the problems they pose.

The governments of Canada and the United States have already experimented with one solution to the problem. During the fall of 1959 the Canadian Government opened the season on Sandhill Cranas at the 
north end of Last Mountain Lake, Saskatchewan. For January 1-30, 1961 , it is open in eastern New Mexico, right up to the fences of the Bitter Lakes National Wildlife Refuge, with two cranes allowed for a bag limit each day and two in possession. One wonders whether the cranes will stay at the Bitter Lakes Refuge once the season opens. What is happening to the cranes under pressure of an open season is being studied in New Mexico this January by Dr. John W. Aldrich and by Dr. Harold S. Peters who has made several trips there and into Saskatchewan this past fall and winter. The results of their finds will give us some insight in to the composition of the flocks wintering in New Mexico.

In centain parts of Mexico, hunting Sandhill Cranes has appiarently been legal for some time. Yet, as far as I know we have made no attempt to study the effects of the open season in Mexico, or the feeding habits and composition of the flocks there.

As a solution to the crane problem an open hunting season has obvious dangers. The two cranes that might suffer the greatest loss are the Whooping Crane and the Greater Sandhill Crane since both these birds are more conspicuous than the Lesser Sandhill Crane.

A more intelligent approach would seem to be that offered by recent articles in the Blue Jay. Since cranes are gregarious, dispersals of flocks is not practical and concentration will undoubtedly become larger in the future as suitable habitat is destroyed. Carefully managed feeding areas are needed for winter concentrations and for concentrations at key points along the cranes' migration route. Naturally, crops raised beside the refuges will suffer damage; probably this grain could be leased and cut for the cranes.

It seems only just to offer compensation to farmers who suffer loss from cranes. There is always the danger of less scrupulous people exaggerating crop losses, but compensation could be based on the difference between the yield of a heavily-pastured field and one where no cranes were feeding.

The damage done during the fall and winter is apparently the main problem. In this paper I have not discussed the spring concentrations throughout North America such as in the Harney County, Oregon, the Platte and North Platite River areas of Nebraska (where at times 100,000 cranes have been counted). However, in talking much with farmers $I$ find that they do not seem bothered by the large number of cranes in spring. Many of them like the cranes and their bugling voices. They know that the cranes eat loose corn in their fields, left over from the fall harvest. They know where the cranes roost but seldom do they disturb them. One man said these concentrations did not occur until the advent of the mechanical corn picker which left much grain on the ground.

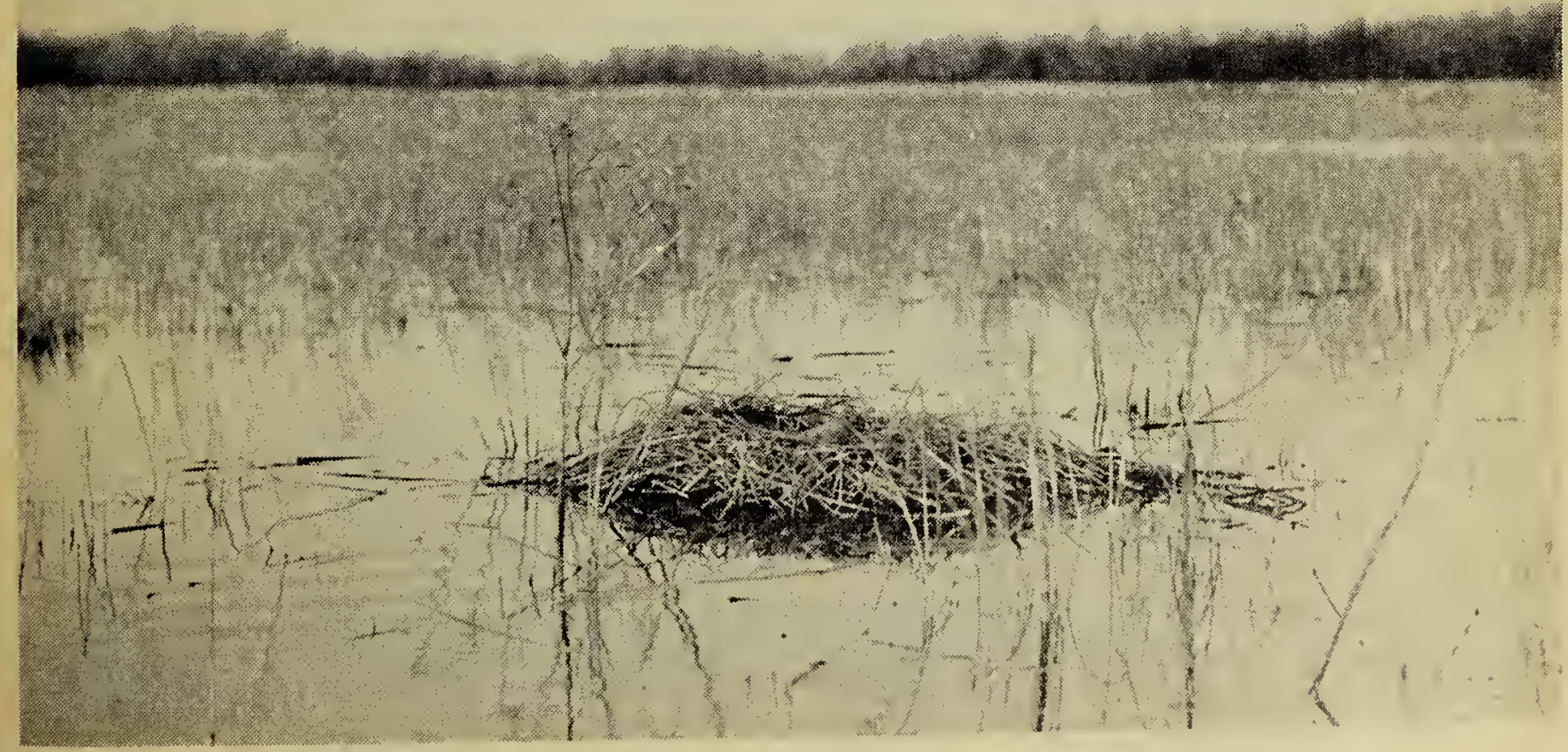

Sandhill Crane nest, Jackson County, Michigan, May 9, 1935. 